\title{
Stable isotope analysis of food sources for salt marsh snails
}

\author{
Kengo Kurata ${ }^{1, *}$, Hiroshi Minami ${ }^{2}$, Eisuke Kikuchi ${ }^{3}$ \\ ${ }^{1}$ Biological Institute, Graduate School of Science, Tohoku University, Sendai 980-8578, Japan \\ ${ }^{2}$ National Research Institute of Far Seas Fisheries, 7-1, Orido 5 chome, Shimizu, Shizuoka 424-8633, Japan \\ ${ }^{3}$ Center for Northeast Asian Studies, Tohoku University Sendai 980-8576, Japan
}

\begin{abstract}
Food sources for the deposit-feeding gastropods Assiminea japonica and Angustassiminea castanea (Gastropoda: Assimineidae) were estimated using stable carbon and nitrogen isotope ratios. We collected animals and potential food materials in reed marshes of the Nanakita River estuary, the eastern part of Miyagi Prefecture, Japan. Feeding experiments were also conducted to confirm whether snails assimilate 4 types of diets. The stable carbon isotope ratios of both assimineid species (mean $\pm 1 \mathrm{SD}:$ A. japonica, $-20.7 \pm 0.3 \%$; A. castanea, $-19.8 \pm 0.5 \%$ ) were closer to that of deposited organic matter from lagoon water $(-20.7 \pm 0.3 \%$ o $)$ than to those of reed litter $(-25.4 \pm 0.1 \%$ o and the surface soil of the reed marsh $(-26.3 \pm 0.1 \%)$. The snails that were fed deposited organic matter showed $\delta^{13} \mathrm{C}$ values similar to the control animals before feeding experiments for both species. The $\delta^{13} \mathrm{C}$ values of the snails fed litter or soil diet, however, revealed that these snails were able to assimilate organic matter from reed detritus under laboratory conditions. These findings suggest that the salt marsh snails utilized mainly deposited organic matter from lagoon water in the field. Microalgae such as phytoplankton and benthic diatoms in deposited matter are considered to be important food sources for 2 species of assimineids inhabiting salt marshes of the Nanakita River estuary.
\end{abstract}

KEY WORDS: Assiminea $\cdot$ Gastropod · Assimilation · Food source $\cdot$ Salt marsh $\cdot$ Stable isotope

Resale or republication not permitted without written consent of the publisher

\section{INTRODUCTION}

Deposit-feeding benthic animals form important links between sedimentary organic matter and carnivores in food chains of estuarine and coastal waters. Estuarine deposit feeders feed on detritus derived from several sources such as rivers, ocean, and adjacent salt marsh plants, but it remains an unsettled question which detrital component is assimilated by these animals. Coastal and estuarine salt marshes where Phragmites spp. or Spartina spp. are prevalent have a high productivity. Litter of vascular plants provides a large amount of organic matter in salt marsh ecosystems (Lee 1990, Moran \& Hodson 1990). However, other

${ }^{*}$ Present address: Ecosystem Engineering, Graduate School of Engineering, The University of Tokushima, 2-1 Minamijyosanjimacho, Tokushima 770-8506, Japan.

E-mail: kengo@eco.tokushima-u.ac.jp types of food sources, including organic matter derived from microalgae, are present in salt marshes, and there has been a controversy whether deposit feeders actually assimilate either of these food sources. For example, Peterson et al. (1985) demonstrated that the relative importance of marsh grass (Spartina) detritus compared to plankton was different by the location of the mussels in the marsh, whereas Sullivan \& Moncreiff (1990) reported that microalgae such as deposited phytoplankton and benthic diatoms are the most important food sources for macrobenthos in salt marshes.

Hitherto most studies of the food sources of depositfeeding animals have used observations of feeding behavior, gut contents, observations of fecal pellets and growth experiments (e.g. Hammond 1983, Uthicke 1999). For macrobenthos inhabiting salt marshes, dissections of alimentary canals of the pulmonate snail Melampus bidentatus and amphipod Orchestia grillus 
revealed that these animals ingested fractions of decaying litter and algae (Thompson 1984), whereas O. grillus digested microorganisms attached to Spartina litter but not litter itself in laboratory feeding experiments (Lopez et al. 1977). However, Rau et al. (1983) suggested the difficulties in evaluating nutritional pathways with only indirect methods, such as analysis of gut contents or feces. It is difficult to elucidate food assimilated by macrobenthos in salt marshes with only the traditional indirect methods.

Recent advances in measurements of stable carbon and nitrogen isotope ratios enabled us to better determine the food sources that animals assimilate. Many food chain studies using isotope ratios, however, estimated the relations between food sources and consumers (or predators) from stable isotope ratios of field samples (e.g. Jackson et al. 1986, Sullivan \& Moncreiff 1990, Hobson \& Welch 1992, Currin et al. 1995, Kikuchi \& Wada 1996, Gu et al. 1997, Kwak \& Zedler 1997), although the stable isotope ratios of animals vary seasonally (Goering et al. 1990), spatially (Deegan \& Garritt 1997), and by temporal growth stages with migrations (Minami \& Ogi 1997). Also, the stable isotope ratios of the food ingested and its consumer are not necessarily consistent because isotope ratios are likely to depend on selective digestion and isotope fractionation during animal metabolism. However, there are few feeding experiments to confirm the isotopical relationships between consumers and their food (e.g. Haines \& Montague 1979). Therefore, it is important to investigate the changes of stable isotope ratios from the food to the consumer by conducting feeding experiments, which can validate the estimated relationships between food sources and consumers in the field. In addition, feeding experiments using quantitative mixtures of diets allow us to determine whether deposit feeders exhibit selective assimilation.

In the present study, we selected deposit-feeding gastropods, Assiminea japonica v. Martens and Angustassiminea castanea (Westerlund) inhabiting salt marshes of the Nanakita River estuary, Miyagi Prefecture, Japan. We tested which food sources these animals assimilated in the field. If these 2 species utilize the same type of food, interspecific competition for food sources may exist, which is important to the coexistence of these 2 species. Both A. japonica and A. castanea belong to the order Mesogastropoda, the radula of which is mainly of the taenioglossate type, allowing these snails to feed on sedimentary particles as deposit feeders. In salt marshes of the Nanakita River estuary, suspended solids are transported with tidal currents and deposited on the substratum. Organic matter derived from reed litter and that from deposited seston is likely to be available to these 2 assimineid species in their habitats. In the present paper, we collected snails and several types of potential food materials available in the field and measured their stable carbon and nitrogen isotope ratios to estimate the main food source of the snails. In addition, feeding experiments using several types of diets were conducted to confirm assimilation and incorporation of these diets, and to test whether these animals selectively assimilated certain diets or not.

\section{MATERIALS AND METHODS}

Field samples. For measurements of stable isotope ratios, we collected individuals of Assiminea japonica and Angustassiminea castanea, surface soil of reed marshes and deposited seston on tidal flats in September 1997. Sampling stations 1, 4, 5 and 6 in the Nanakita River estuary were located in the reed marsh, station (Stn) 3 was at the border of the reed marsh and the tidal flat, and Stn 2 was located in the tidal flat $5 \mathrm{~m}$ toward the lagoon from Stn 3 (Fig. 1). Stns $2,3,4$ and 5 were located along the transect line set perpendicularly from the tidal flat to the reed marsh. Relative height above mean seawater level was the lowest at Stn 2 and highest at Stn 5 along a transect line. Assimineid snails were distributed mainly in reed marshes, and densities of $A$. japonica and A. castanea along this transect line were highest at Stns 4 and 5, respectively (Kurata \& Kikuchi 1999).

Surface soil to $5 \mathrm{~mm}$ sediment depth was sampled at Stns 1, 3, 4, 5 and 6, put into Uni-Packs and stored at $-21^{\circ} \mathrm{C}$ (samples of surface soil from reed marshes were abbreviated S1, S3, S4, S5 and S6, respectively). For collection of deposited seston at the tidal flat, petri dishes (90 $\mathrm{mm}$ in diameter) were set at Stn 2 and retrieved $24 \mathrm{~h}$ later. The mixture of deposited seston and water in the petri dishes was centrifuged at $5000 \mathrm{rpm}$ for $10 \mathrm{~min}$, and the settled sediments were placed into Uni-Packs and stored at $-21^{\circ} \mathrm{C}$ (samples of deposited seston at tidal flats were abbreviated D2a and D2b for the different sampling days). An observation on deposited seston collected at the tidal flat using a binocular microscope revealed that there were many diatoms, detritus derived from unknown organic matter, copepods and fine inorganic particles. A quantitative assessment of the composition of these materials, however, was not carried out because it was difficult to estimate the amount of these components.

Individuals of Assiminea japonica ( $\mathrm{n}=13$, approximately $6.5 \mathrm{~mm}$ in shell height) and Angustassiminea castanea ( $\mathrm{n}=13$, approximately $5 \mathrm{~mm}$ in shell height) were collected at Stns 4 and 5 on 1 date, put into UniPacks and stored at $-21^{\circ} \mathrm{C}$ (samples of snails were abbreviated $\mathrm{J} 4$ and $\mathrm{C} 5$, respectively). The stable isotope ratios of these snail samples (J4 and C5) were 


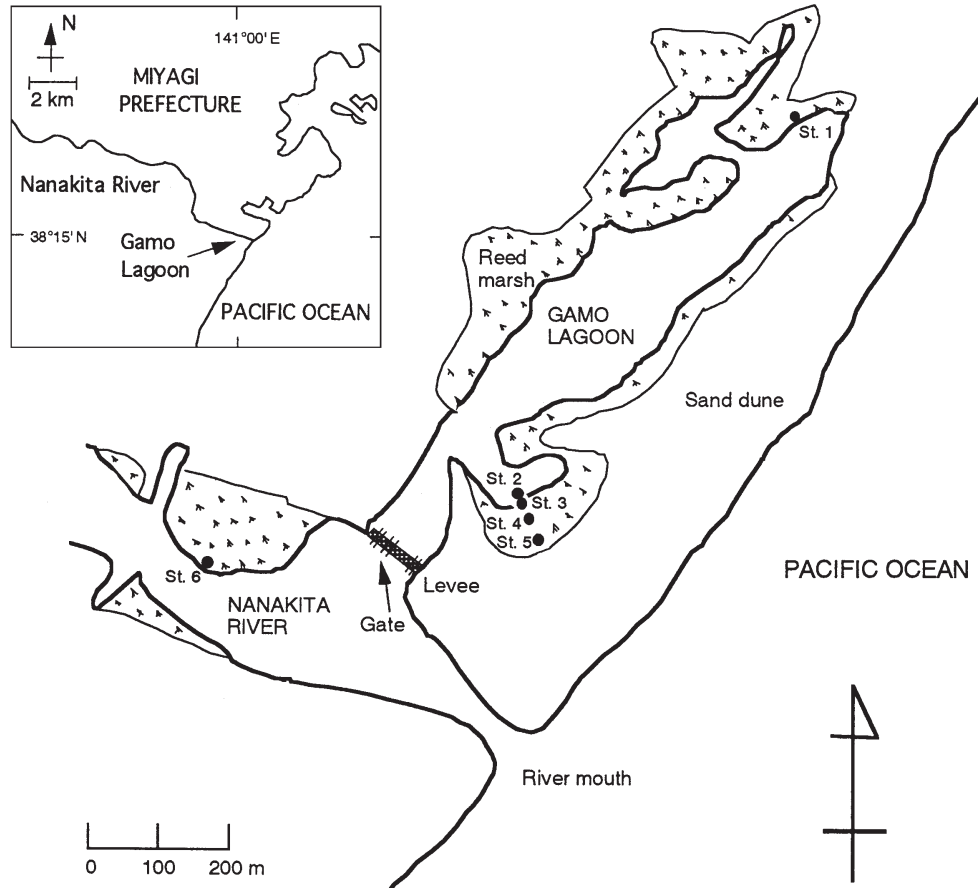

Fig. 1. Map of study sites. Six sampling stations (Stns 1, 2, 3, 4, 5, 6) are shown

deposited seston, soil) was measured as loss of weight on ignition at $700^{\circ} \mathrm{C}$ for $2 \mathrm{~h}$.

Feeding experiments. Snails were reared with different types of diets to measure changes in stable carbon and nitrogen isotope ratios. Individuals of Assiminea japonica ( $\mathrm{n}=68$, approximately $6.5 \mathrm{~mm}$ in shell height) and Angustassiminea castanea ( $\mathrm{n}=68$, approximately $5 \mathrm{~mm}$ in shell height) were collected in September 1997 at Stns 4 and 5. In the laboratory, shell heights of snails were measured, and they were marked with a manicure paint. Plastic petri dishes (90 $\mathrm{mm}$ in diameter) placed on a filter paper with $5 \mathrm{ml}$ filtered seawater (1/3 dilution with distilled water) were prepared for rearing containers. We reared snails in petri dishes containing no diet for $7 \mathrm{~d}$ before starting the feeding experiment. Four individuals of either species were put into a dish. In addition to the 4 types of diets described above, a mixture of these 4 diets and no diet were also included as treatments. The first 5 treatments were assigned to 3 petri dishes per

treated as baselines in the feeding experiments (see below), and were included in statistical analyses.

Preparation of diets for feeding experiments. Four types of diets were prepared for feeding experiments. Procedures for preparation of these diets follow. Diatom: red algae (Gracilaria vermiculophylla) was collected at Stn 2 and diatom cells (Nitzschia sp.) attached to them were separated and cultured in the medium of seawater (Miquel type). The culture medium containing diatoms was centrifuged at $5000 \mathrm{rpm}$ for $10 \mathrm{~min}$. The residue was put into a petri dish and dried at $70^{\circ} \mathrm{C}$ for $24 \mathrm{~h}$. These dried diatoms were ground with a mill to a fine powder and stored in a desiccator. Litter: decayed brown litter of reed leaves (Phragmites spp.) lying on the substratum was collected at Stn 4 . In the laboratory, litter was rinsed with fresh water to remove sediment and dried at $70^{\circ} \mathrm{C}$ for $24 \mathrm{~h}$. The dried litter was cut with an electric mill into fine particles $(<2 \mathrm{~mm})$ and stored in a desiccator. Deposited seston: petri dishes (90 $\mathrm{mm}$ in diameter) were placed on the surface of the tidal flat at Stn 2 for $7 \mathrm{~d}$. Deposited seston in the dishes was decanted carefully to centrifuge tubes so as to avoid transferring large sandy particles, and was centrifuged at $5000 \mathrm{rpm}$ for $10 \mathrm{~min}$. The residue was put into a petri dish, dried at $70^{\circ} \mathrm{C}$ for $24 \mathrm{~h}$, and stored in a desiccator. Soil: surface soil to $5 \mathrm{~mm}$ sediment depth was sampled at Stn 4 , dried at $70^{\circ} \mathrm{C}$ for $24 \mathrm{~h}$ and stored in a desiccator. Organic matter content of the 4 types of experimental food substances (diatom, litter, species for each treatment, and the latter treatment (no diet) was assigned to 2 petri dishes per species. Four individuals were transferred into a new petri dish and provided with each diet every $3 \mathrm{~d}$. For each type of diet, $20 \mathrm{mg}$ of organic matter by dry weight was assigned to 4 snails for $3 \mathrm{~d}$. For the mixture diet, each type of diet containing $5 \mathrm{mg}$ of organic matter was fed to 4 snails for $3 \mathrm{~d}$. Feeding experiments were conducted at $21^{\circ} \mathrm{C}$ for a month. After experiments were completed, all snails were stored at $-21^{\circ} \mathrm{C}$. We took photographs of some of the petri dishes from the top side of the dishes using a dissecting binocular microscope photosystem, and counted the number of fecal pellets in an oval shape on the filter paper and food in the photographs. We then calculated the number of fecal pellets egested by a snail during each $3 \mathrm{~d}$ period, from the area of a petri dish and the number of snails. After the effects of the dietary treatments on the number of fecal pellets were evaluated by Kruskal-Wallis test, we compared the mean values among the 6 dietary treatments using Mann-Whitney $U$-test.

Measurements of stable isotope ratios. Samples for measurements of stable carbon and nitrogen isotope ratios were prepared by the following procedures. Snails: after shells were broken, fractions of the shell and the operculum were carefully removed with tweezers under a dissecting binocular microscope. Soft bodies were individually put into a hard-glass vial and freeze-dried for $24 \mathrm{~h}$. We then poured a chloroform- 
Table 1. Summary of $\delta^{13} \mathrm{C}(\%), \delta^{15} \mathrm{~N}(\%)$, carbon content (\%), nitrogen content (\%), and C/N values of diets and snails (Assiminea japonica, Angustassiminea castanea) in the feeding experiments. Means, standard deviations and number of samples measured for diets and number of individuals for snails (n) are shown below

\begin{tabular}{|c|c|c|c|c|c|}
\hline & $\delta 13 \mathrm{C}$ & $\delta 15 N$ & Carbon & Nitrogen & $\mathrm{C} / \mathrm{N}$ \\
\hline \multicolumn{6}{|l|}{ Diets } \\
\hline Litter & $-25.4 \pm 0.1(2)$ & $10.4 \pm 0.4(3)$ & $44.8 \pm 0.5(2)$ & $1.6 \pm 0.0(2)$ & $27.2 \pm 0.5(2)$ \\
\hline Soil & $-26.3 \pm 0.1$ & $8.8 \pm 0.1(3)$ & $2.6 \pm 0.2$ & $0.2 \pm 0.0$ & $14.0 \pm 0.3$ \\
\hline Deposited seston & $-20.7 \pm 0.3$ & $9.6 \pm 0.3$ & $2.0 \pm 0.1$ & $0.2 \pm 0.0$ & $9.3 \pm 0.3$ \\
\hline Diatom & $-13.5 \pm 0.2(3)$ & $3.9 \pm 0.1$ & $1.6 \pm 0.2(3)$ & $0.3 \pm 0.0$ & $4.8 \pm 0.1$ \\
\hline \multicolumn{6}{|l|}{ Snails } \\
\hline A. japonica (J4) & $-20.7 \pm 0.3(13)$ & $9.7 \pm 0.5(13)$ & $39.2 \pm 1.7(9)$ & $10.9 \pm 1.0(9)$ & $3.6 \pm 0.2(9)$ \\
\hline A. castanea (C5) & $-19.8 \pm 0.5(13)$ & $9.3 \pm 0.3(12)$ & $38.2 \pm 1.2(9)$ & $11.0 \pm 0.6(8)$ & $3.5 \pm 0.1(8)$ \\
\hline
\end{tabular}

methanol mixture (the mixture ratio was $2: 1$ ) into the vials to extract lipids for $24 \mathrm{~h}$. Samples in the vials were filtered on glass filter paper (Whatman GF/F) using a vacuum pump to remove lipids and the chloroformmethanol mixture. The samples on the filter paper were put into the vials and freeze-dried for $24 \mathrm{~h}$. Soil and deposited seston: soil and deposited seston were put into vials and freeze-dried for $24 \mathrm{~h}$. Then, $1 \mathrm{M} \mathrm{HCl}$ solution was poured into vials with freeze-dried samples for $24 \mathrm{~h}$ to remove carbonates. After removal of the $\mathrm{HCl}$ solution, the samples in the vials were freezedried for $24 \mathrm{~h}$. All samples prepared with these procedures were kept in a freezer at $-21^{\circ} \mathrm{C}$ until measurement of stable isotope ratios.

Stable carbon isotope ratios $\left(\delta^{13} \mathrm{C}\right)$, stable nitrogen isotope ratios $\left(\delta^{15} \mathrm{~N}\right)$, carbon content in dry weight $(\mathrm{C}$ $\%)$, nitrogen content in dry weight ( $\mathrm{N} \%)$ and car-

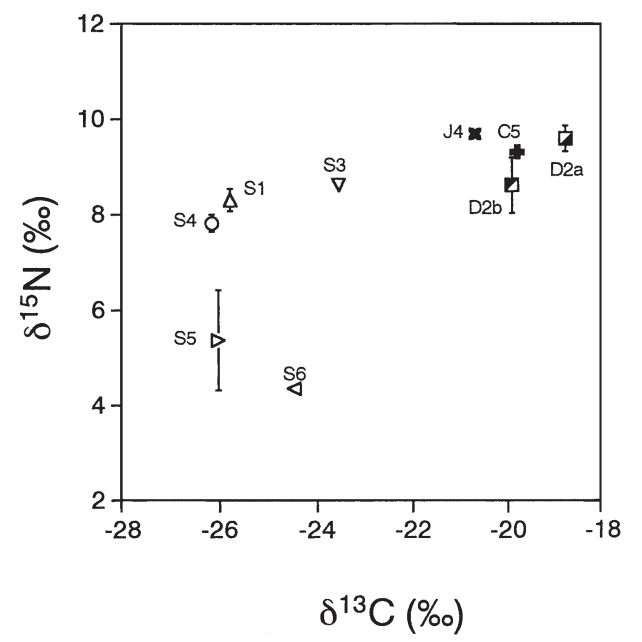

Fig. 2. Stable carbon and nitrogen isotope ratios (mean $\pm 1 \mathrm{SE})$ of field samples (J4 [n = 13] Assiminea japonica; C5 [n = 13], Angustassiminea castanea; D2a [n = 3], D2b [n = 2], deposited seston collected at Stn 2 on different sampling days; S1 [n=4], S3 [n = 4], S4 [n=4], S5 [n=3], S6 [n=3], surface soil of reed marshes at Stns $1,3,4,5,6$, respectively) bon/nitrogen ratio $(\mathrm{C} / \mathrm{N})$ were measured using an elemental analyzer and a mass spectrometer (Finnigan MAT 252) at the National Institute for Environmental Studies. Isotope ratios were expressed as relative values (\%) as defined by the following equation:

$$
\delta^{13} \mathrm{C}, \delta^{15} \mathrm{~N}=\left(R_{\text {sample }}-R_{\text {standard }}\right) / R_{\text {standard }} \times 1000
$$

where $R={ }^{13} \mathrm{C} /{ }^{12} \mathrm{C}$ or ${ }^{15} \mathrm{~N} /{ }^{14} \mathrm{~N}$. Peedee belemnite and atmospheric nitrogen were used as the carbon and nitrogen isotope standards, respectively. The stable isotope ratios of snail samples in the field (J4 and C5) were treated as baselines in the feeding experiments and were included in statistical analyses. For $\delta^{13} \mathrm{C}$ and $\delta^{15} \mathrm{~N}$ of the snails before experiments and those in the 6 dietary treatments, 1-way analysis of variance (ANOVA) was conducted to test the effects of the dietary treatments after ensuring the homogeneity of variances among the data using the Bartlett test. Assuming that there were no interactions of feeding behavior among the 4 individuals in a rearing dish, we took the isotopical value of an individual to be an element for calculating the means.

\section{RESULTS}

\section{Field samples}

Means and standard deviations of stable isotope ratios of the field samples are shown in isotopic crossplots with $\delta^{13} \mathrm{C}$ as horizontal axis and $\delta^{15} \mathrm{~N}$ as vertical axis (Fig. 2). The $\delta^{13} \mathrm{C}$ values of both Assiminea japonica (J4) and Angustassiminea castanea (C5) were much closer to those of deposited seston (D2a, D2b) than to those of soils (S1, S3, S4, S5, S6). The $\delta^{15} \mathrm{~N}$ values of these 2 species were close to those of deposited seston (D2a, D2b) and some of the soils (S1, S3, S4). The $\delta^{15} \mathrm{~N}$ values of soils at Stns 1,3 and $4(\mathrm{~S} 1, \mathrm{~S} 3, \mathrm{~S} 4)$ were higher than those at Stns 5 and 6 (S5, S6). The differences of means of $\delta^{13} \mathrm{C}$ and $\delta^{15} \mathrm{~N}$ between the 2 
(a) A. japonica

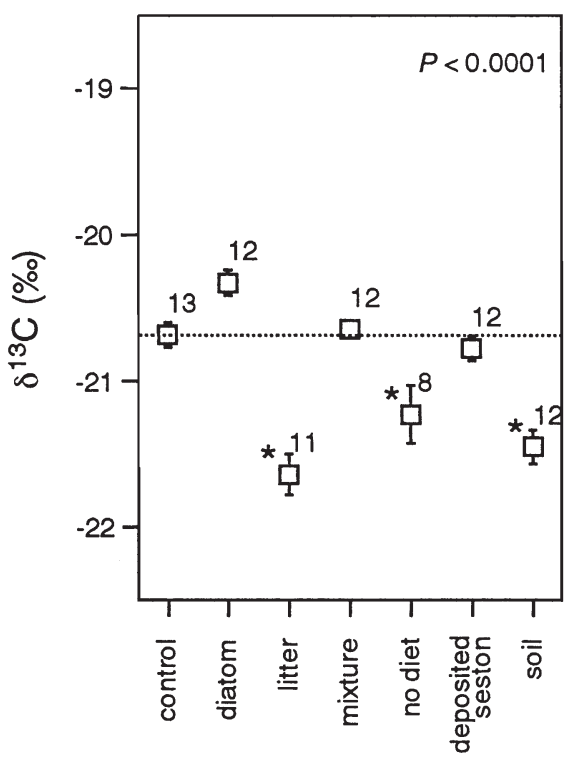

(b) A. castanea

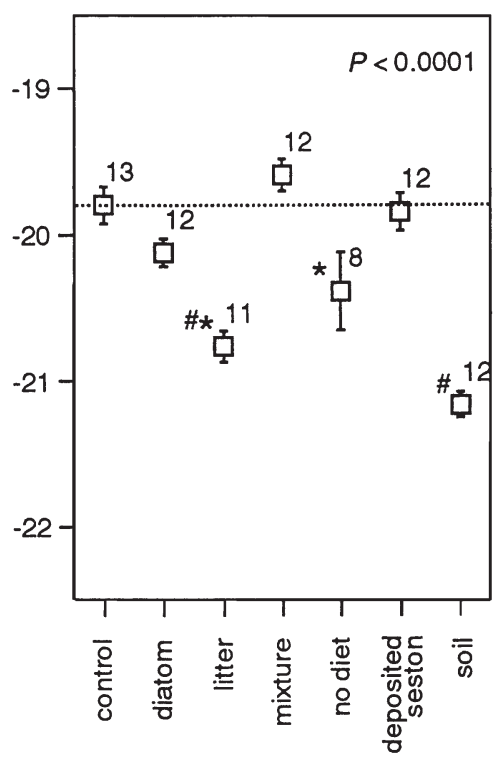

Dietary type and control

Fig. 3. Stable carbon isotope ratio (mean $\pm 1 \mathrm{SE}$ ) of Assiminea japonica (a) and Angustassiminea castanea (b) of feeding experiments, and the p-values for the treatment effect (1-way ANOVA). Dotted line indicates experimental control. Asterisks and sharps indicate significant differences from the control. There is no significant difference among diet litter, soil and no diet, except in the combination soil and no diet for A. castanea $(\mathrm{p}<0.001)$. Number of individuals for each treatment is shown above the plot. For the carbon stable isotope ratios of the diets, see Table 1

species were small (about $0.9 \%$ and $0.4 \%$, respectively).

\section{Stable isotope ratios and $\mathrm{C} / \mathrm{N}$ in feeding experiments}

$\delta^{13} \mathrm{C}, \delta^{15} \mathrm{~N}$, carbon content $(\mathrm{C} \%)$, nitrogen content ( $\mathrm{N} \%$ ) and $\mathrm{C} / \mathrm{N}$ of 4 types of dietary substances (diatom, litter, deposited seston, soil) and the control snails ( $\mathrm{J} 4$ and $\mathrm{C} 5$ ) in the feeding experiments are shown in Table 1. The $\delta^{13} \mathrm{C}$ of litter was closer to that of the soil, but the values for deposited seston and diatoms were different from those of litter and soil. The $\delta^{15} \mathrm{~N}$ values of litter, soil and deposited seston ranged between $8.5 \%$ and $10.5 \%$ while that of the diatoms was about $4 \%$. The $\mathrm{C} / \mathrm{N}$ of litter was the highest and that of the diatoms was the lowest. Since the diatom diet was processed using a centrifuge in order to remove extra water and dried at $70^{\circ} \mathrm{C}$ for 24 $\mathrm{h}$, the samples of diatom diet seemed to have contained much inorganic matter $(\mathrm{NaCl})$, thus resulting in

unusually low contents (\%) of carbon and nitrogen. The $\delta^{13} \mathrm{C}$ and $\delta^{15} \mathrm{~N}$ of the snails ( $\mathrm{J} 4$ and $\mathrm{C} 5$ ) were close to those of deposited seston.

The effects of the dietary treatments on the $\delta^{13} \mathrm{C}$ values were significant for both Assiminea japonica and Angustassiminea castanea ( $\mathrm{p}<$ 0.0001; Fig. 3). Differences in the stable isotope ratios between experiment and control treatments were found in some cases. For A. japonica and $A$. castanea, the $\delta^{13} \mathrm{C}$ values after feeding experiments with 3 food substrate treatments (litter, no diet, soil) were significantly lower than those before experiments (Bonferroni/Dunn's multiple comparison

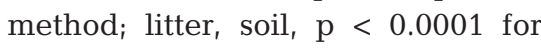
both species; no diet, $\mathrm{p}<0.005$ for both species; Fig. 3). The $\delta^{13} \mathrm{C}$ values in the other 3 food substrate treatments (diatom, mixture, deposited seston) showed similar values to the control even after snails had fed on these food materials. The effect of the dietary treatments on the $\delta^{15} \mathrm{~N}$ of snails was significant for $A$. castanea (ANOVA, $\mathrm{p}<0.0001$; Fig. 4), but not significant for $A$. japonica (ANOVA, $\mathrm{p}>0.05$; Fig. 4). The $\delta^{15} \mathrm{~N}$ values of snails did not differ from those of controls except that $A$. castanea reared on diatoms showed significantly lower $\delta^{15} \mathrm{~N}$ than before feeding experiments (Bonferroni/Dunn's multiple comparison method, $\mathrm{p}<0.0001$; Fig. 4).

\section{Number of fecal pellets}

The Kruskal-Wallis test for the number of fecal pellets voided by each species showed that the effects of the dietary treatments were significant for both species (both species $\mathrm{p}<0.0001$; Fig. 5). The number of fecal pellets in the mixed dietary treatment showed the highest values of all treatments for both species (Mann-Whitney $U$-test, $\mathrm{p}<0.001$ for all combinations, except mixture versus deposited seston for Angustassiminea castanea, $\mathrm{p}<0.01$; Fig. 5). The number of fecal pellets in the soil diet was not significantly different from those in the litter and deposited seston treatments for A. castanea (MannWhitney $U$-test, $p>0.05$; Fig. 5), and the number of fecal pellets in the soil diet was not significantly different from that in the litter diet treatment for Assiminea japonica (Mann-Whitney $U$-test, $\mathrm{p}>0.05$; Fig. 5). 
(a) A. japonica

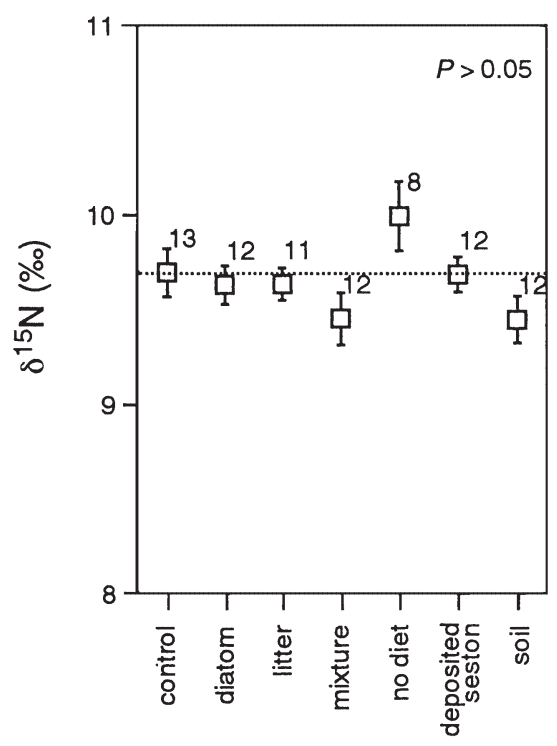

(b) A. castanea

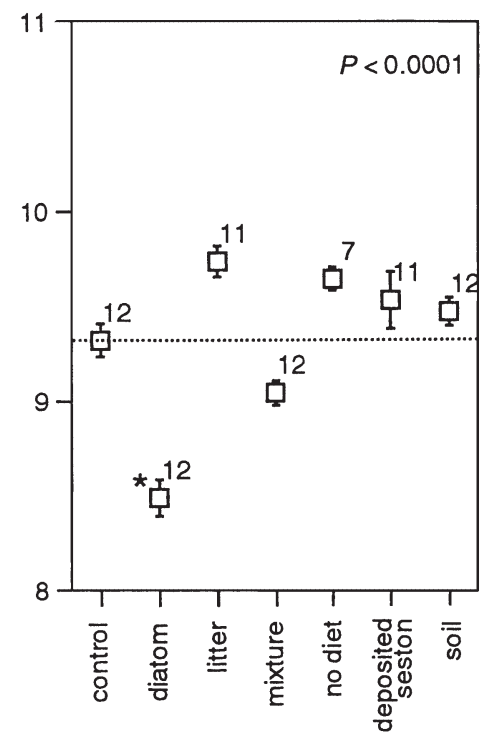

\section{Dietary type and control}

Fig. 4. Stable nitrogen isotope ratio (mean $\pm 1 \mathrm{SE}$ ) of Assiminea japonica (a) and Angustassiminea castanea (b) of feeding experiments, and the p-values for the treatment effect (1-way ANOVA). Dotted line indicates experimental control. ${ }^{*}$ Significant difference from the control. Number of individuals for each treatment is shown above the plot. For the nitrogen stable isotope ratios of the diets, see Table 1

\section{DISCUSSION}

\section{Field samples}

Because estuarine salt marshes were submerged during high tides, organic matter of surface soil can originate from several sources: litter of salt marsh plants, deposited seston from water, and benthic algae growing on the surface. In the present study, the $\delta^{13} \mathrm{C}$ value of the surface soil $(-26.3 \%$ ) was more similar to that of reed litter $(-25.4 \%$ ) than to that of deposited seston $(-20.7 \%$ ) collected at the tidal flat (Table 1). However, $\mathrm{C} / \mathrm{N}$ of the surface soil was 14.0 compared to 27.2 for the reed litter. Soils could be a mixture of deposited seston, fecal pellets, decomposed litter and microbial biomass. Hullar et al. (1996) suggested that the microbial $\delta^{13} \mathrm{C}$ values in the field are similar to the carbon assimilated by bacteria. Gosselink \& Kirby (1974) reported that the conversion efficiency to microbial biomass for the particles of salt marsh grass Spartina alterniflora ranged from $28 \%$ to over $60 \%$. Because the $d^{13} \mathrm{C}$ value of the soil in the present study was similar to that of the reed litter, it is estimated that the organic matter in the soil was mainly derived from that in reed detritus and microbial biomass. Surface soil was considered to be comprised of a large amount of organic matter derived from reed litter.

Values of $\delta^{13} \mathrm{C}$ generally remain nearly constant throughout the food chain, or there is an about $1 \%$ o enrichment with each trophic step (Fry \& Sherr 1984). That is, the $\delta^{13} \mathrm{C}$ value of a consumer is often close to that of the assimilated diet. The $\delta^{13} \mathrm{C}$ values of Assiminea japonica and Angustassiminea castanea were similar to those of deposited seston, but not similar to the $\delta^{13} \mathrm{C}$ for either the surface soil or reed litter (Fig. 2, Table 1). Organic matter deposited onto the tidal flats was available to A. japonica and A. castanea inhabiting reed marshes, because suspended solids and phytoplankton were probably deposited onto the substratum during high tides. If these 2 species had assimilated organic matter from reed litter exclusively, their $\delta^{13} \mathrm{C}$ values would probably be much lower. Also, if the snails could feed on finely particulate reed detritus in the soil, the $\delta^{13} \mathrm{C}$ of the snails would have shown much lower values. Assimineid snails are unlikely to feed directly on litter because they ingest food particles as depositfeeders, picking up particles with taenioglossate radulae (authors' pers. obs.). Therefore $A$. japonica and $A$. castanea were considered to make use of organic matter in deposited seston rather than in the soil or reed litter, even in reed marshes.

For the $\delta^{15} \mathrm{~N}$ values of the field samples, Assiminea japonica and Angustassiminea castanea had values of about $9.5 \%$, which were very close to those of deposited seston and also overlapped with the $\delta^{15} \mathrm{~N}$ of reed litter (Fig. 2, Table 1). Similar values of $\delta^{15} \mathrm{~N}$ in assimineid gastropods and deposited seston were consistent with values of the carbon stable isotope ratios, implying that the snails' main food source was deposited seston. However, many studies estimating food chains apply the assumption that nitrogen stable isotope ratios increase about $3 \%$ to $4 \%$ with each trophic transfer (Minagawa \& Wada 1984, Wada et al. 1987). This general rule is known to be appropriate for pelagic food chains, but empirical coefficients of isotopical fractionation for grazing animals may not be applied to the microbial loop (Yamada \& Yoshioka 1999). Experimental analysis and explanations have not yet been presented as to why $\delta^{15} \mathrm{~N}$ fractionation between consumer and food is generally within a range from $3 \%$ to $5 \%$ o (Matsubara \& Minami 1998). In the following we discuss the possible reasons why the 
$\delta^{15} \mathrm{~N}$ of snails in the present study did not show enrichment with each trophic step. Detritus in coastal estuarine ecosystems is an aggregation of materials from various origins, and detritus-feeding benthos may assimilate detritus selectively (Clough \& Lopez 1993). Kikuchi \& Wada (1996) found unexpected differences in $\delta^{15} \mathrm{~N}$ between sedimentary organics and corresponding polychaetes, and considered that they were attributable to selective assimilation of bacterial $\mathrm{N}$ or bacterially altered compounds in the diet. Additionally, there is a report that the process of microbial degradation should result in an overall decrease in the $\delta^{15} \mathrm{~N}$ value (Currin et al. 1995). We consider that the $\delta^{15} \mathrm{~N}$ of snails was not enriched, because a large amount of deposited seston had different $\delta^{15} \mathrm{~N}$ values from those fractions selectively assimilated by these snails. Benner et al. (1991) concluded that stable $\mathrm{N}$ isotope compositions do not appear to be as applicable for tracing $\mathrm{N}$ flow and trophic relationships in detritus-based food webs as they are in grazing-based food webs. Hobson \& Welch (1992) considered that it is inappropriate to expect a consistent nitrogen fractionation value between all trophic levels. France (1996) considered that $\delta^{15} \mathrm{~N}$ loses its strength as an unambiguous marker of absolute trophic position in complex ecotonal food webs such as those in estuarine environments. The isotopical fractionation of nitrogen may differ between benthic and pelagic food chains in marine ecosystems. It may be precarious to apply the conventional rule of a $3 \%$ to $4 \%$ difference between $\delta^{15} \mathrm{~N}$ from diet to consumer in detritus feeders. Consequently, we tried to confirm isotopical relations between the assimineid snails and their food sources through feeding experiments.

\section{Feeding experiments}

The drop in $\delta^{13} \mathrm{C}$ values of the snails in litter or soil dietary treatments for both Assiminea japonica and Angustassiminea castanea compared to those of control animals (snails before experiments) (Fig. 3) indicated assimilation of organic matter from the soil or the litter diets (Table 1), because, for both species, the snails fed litter or soil egested fecal pellets (Fig. 5). These findings also suggested that the snails inhabiting reed marshes did not utilize organic matter derived from litter and surface soil as main food sources, because the $\delta^{13} \mathrm{C}$ values of the snails collected in the field were significantly different from those fed litter or (a) A. japonica

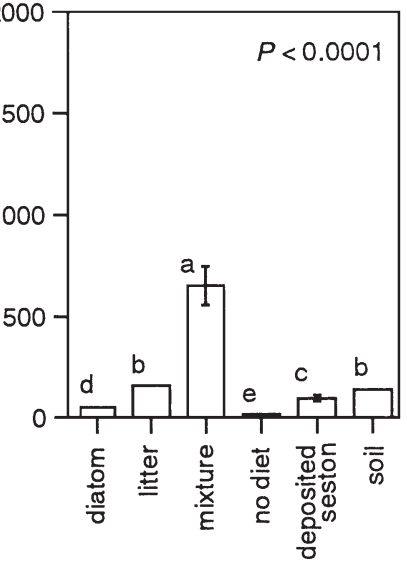

(b) A. castanea

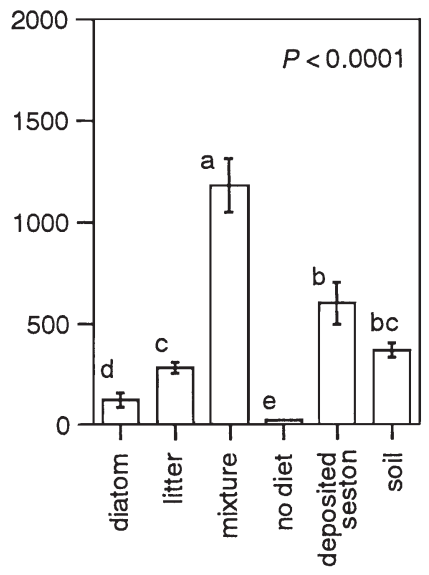

\section{Dietary type}

Fig. 5. Number of fecal pellets (mean $\pm 1 \mathrm{SE}, \mathrm{n}=9$ ) of Assiminea japonica (a) and Angustassiminea castanea (b) of feeding experiments, and the p-values for the treatment effect (Kruskal-Wallis test). Different letters indicate means were significantly different from each other (Mann-Whitney $U$-test)

soil in the feeding experiments. The observed effects on $\delta^{13} \mathrm{C}$ in the feeding experiments were small but statistically significant. Sufficient replicates of individuals allowed us to detect the small isotopic effects of dietary treatments in the feeding experiments.

The $\delta^{13} \mathrm{C}$ values of the snails fed deposited seston were not significantly different from those of control animals for both species (Fig. 3). The snails fed the diet of deposited seston egested as many fecal pellets as those fed litter or soil (Fig. 5). Optimal foraging theory and physiological homeostasis models predict that animals increase their ingestion rate with increasing food quality until the level set by physiological limits is reached, as digestion is a time-dependent process (Heip et al. 1995). That is, the snails would process high-quality material faster than poor-quality material. The amount of fecal pellets was considered to be more or less reflected by the amount of diet ingested. These findings suggested that the snails had assimilated organic matter from the deposited seston that had $\delta^{13} \mathrm{C}$ values close to those of the control snails (Table 1). The field samples indicated that the main food source of assimineid snails was the organic matter in deposited seston. Moreover, the feeding experiments revealed that snails could utilize not only deposited seston, but also organic matter in the litter or soil. It is safe to say that snails utilize deposited seston as a main food source in the field, although they were able to ingest and assimilate fractions of reed litter or organic matter in the surface soil under experimental conditions. 
Vascular plants with high $\mathrm{C} / \mathrm{N}$ ratios from land contain large amounts of refractory substances, such as cellulose and lignin, which are indigestible by invertebrate animals (Kristensen 1972), while phytoplankton with a low $\mathrm{C} / \mathrm{N}$ ratio contains high amounts of easily decomposable substances such as protein and carbohydrates. Detritus-feeding animals are unable to utilize plant detritus directly (Kristensen 1972), because they often do not have the appropriate digestive enzymes or digestive symbionts (Hodson et al. 1984). Consequently, these animals are considered to assimilate bacteria, heterotrophic protozoa feeding on the bacteria and some materials decomposed by bacteria (Gosselink \& Kirby 1974, Lopez et al. 1977, Thompson 1984). Yingst (1976) considered that bacteria are a potential source of nutrition for organisms ingesting particulate detrital material in aquatic environments. The high nitrogen contents or low $\mathrm{C} / \mathrm{N}$ ratios seem to indicate detritus of high quality as a food for depositfeeding animals (Newell 1965, Tenore 1977, 1981, Grebmeier et al. 1988). Since the $\delta^{13} \mathrm{C}$ value of soil was similar to that of reed litter (Table 1), organic matter of the soil was estimated to be derived mostly from reed litter. However, $\mathrm{C} / \mathrm{N}$ of the surface soil (14.0) compared to that of the reed litter (27.2) suggested that the organic matter originating from reed litter was enriched in $\mathrm{N}$ by microbial decomposers, or the relative accumulation of refractory $\mathrm{N}$-containing compounds. During the degradation of vascular plant detritus containing little nitrogen, the $\mathrm{C} / \mathrm{N}$ ratio tends to decrease with time and to approach a ratio of approximately 10:1 asymptotically (Alexander 1977), while phytoplankton and algae with a $\mathrm{C} / \mathrm{N}$ ratio $<10$ are decomposed by microbial activities, and the $\mathrm{C} / \mathrm{N}$ ratios gradually increase to nearly 10. Hedges et al. (1988) reported that the organic matter of deeper sediment in the inner bay has a $\mathrm{C} / \mathrm{N}$ ratio of approximately 10 , indicating that organic matter which was decomposed for a long time has a $\mathrm{C} / \mathrm{N}$ ratio of 10 . Decay experiments with detritus derived from eel grass showed an initial rapid decrease, then a slower rate of increase in nitrogen content, and corresponding changes in $\mathrm{C} / \mathrm{N}$ ratios (Tenore 1975). The increase in nitrogen content probably reflects both a loss of more labile compounds, especially water-soluble sugars and carbohydrates, from the plant material and the development of a microbial flora (Tenore 1975). The $\delta^{13} \mathrm{C}$ of snails fed fractions of reed litter or soil shifted to lower values, more similar to those of diets in the feeding experiments (Fig. 3). The snails may have selectively assimilated bacteria biomass and organic matter from reed litter decomposed through microbial activity.

The snails of both species fed a mixed diet egested more fecal pellets than those in other dietary treatments (Fig. 5). Since the amount of fecal pellets was reflected by the amount of diet ingested as discussed above, the ingestion rate of the mixed diet was considered to be higher than that of the other diets. In addition, the $\delta^{13} \mathrm{C}$ values of snails fed the mixed diet were significantly higher than those fed litter or soil, but not significantly different from the $\delta^{13} \mathrm{C}$ of control snails or snails fed deposited seston. Since the mixed diet consisted of 4 types of food substances (each of which comprised $5 \mathrm{mg}$ of organic matter), from soil with the lowest $\delta^{13} \mathrm{C}(-26.3 \%)$ to the diatom diet with the highest $\delta^{13} \mathrm{C}(-13.5 \%)$, the $\delta^{13} \mathrm{C}$ of the mixed diet was expected to be approximately $-24 \%$. However, the $\delta^{13} \mathrm{C}$ values of snails fed the mixed diet did not significantly differ from the $\delta^{13} \mathrm{C}$ of control snails and those of snails fed deposited seston. The snails may have efficiently or selectively assimilated the organic carbon of the deposited seston constituent of the mixture, rather than assimilating the organic carbon from each constituent.

In the no diet treatment, the $\delta^{13} \mathrm{C}$ values were significantly lower than those of control snails for both species (Fig. 3). Although we have no information to explain this, snails in starved condition may have metabolized a somatic component of a higher $\delta^{13} \mathrm{C}$ value. Hobson et al. (1993) reported that starved quail (Coturnix japonica) enrich their tissue $\delta^{15} \mathrm{~N}$ value, indicating the importance of the physiological condition of animals in the interpretation of stable isotope ratios. The fact that the $\delta^{13} \mathrm{C}$ of the snails was depleted in the no diet treatment also suggests that the $\delta^{13} \mathrm{C}$ of snails fed deposited seston did not change because they assimilated organic matter from deposited seston.

The effects of dietary treatments on the $\delta^{15} \mathrm{~N}$ values were significant for Angustassiminea castanea, but not for Assiminea japonica (Fig. 4). Except for A. castanea fed cultured diatoms, the $\delta^{15} \mathrm{~N}$ of the snails was not significantly different from those of control snails (Fig. 4). The $\delta^{15} \mathrm{~N}$ of litter, soil and deposited seston ranged from 8.5 to $10.5 \%$, which was similar to values for control snails (Table 1). Although it is possible that the snails selectively fed on components of lower $\delta^{15} \mathrm{~N}$ within these diets, the nitrogen stable isotope ratios do not seem to have changed when the snails assimilated these diets. However, these results suggest that the conventional rule of an about 3 to $4 \%$ olevation of $\delta^{15} \mathrm{~N}$ from the diet to the consumer may not be applicable to these assimineid snails, and further detailed studies need to be done on fractionation of nitrogen isotopes in these animals.

It is generally agreed that phytoplankton are digestible and suitable food for benthic detritus feeders. In the feeding experiments, only a few numbers of fecal pellets were egested by both species when they were fed a diatom diet (Fig. 5). Were the cultured diatoms suitable food? Because both $\delta^{13} \mathrm{C}$ and $\delta^{15} \mathrm{~N}$ values of the 
cultured diatoms were very distinct from those of the control snails (Table 1), the stable isotope ratios would have changed if these snails had assimilated the diatom diet. However, the $\delta^{13} \mathrm{C}$ of Angustassiminea castanea and the $\delta^{13} \mathrm{C}$ and the $\delta^{15} \mathrm{~N}$ of Assiminea japonica did not change. Only in the case of $A$. castanea was $\delta^{15} \mathrm{~N}$ depleted in the treatment with a diatom diet (but $<1 \%$ ). Because the diatom diet was not collected from the field but cultured in the laboratory from field-isolated diatoms and dried at $70^{\circ} \mathrm{C}$ for $24 \mathrm{~h}$, we speculated that the nutritional value for the snails differed from that of the diatoms in the deposited seston.

The cultured diatoms seemed to be unsuitable for these assimineid snails, especially for Assiminea japonica. The cultured diatoms may have contained some bacteria, since the culture was mono-algal but not free of bacteria. Angustassiminea castanea may have selectively assimilated only a portion of the organic matter from the diet provided. There is little information on the feeding ecology of the 2 species, although their distributions and life histories are different from each other (Kurata \& Kikuchi 1999, 2000). Since A. castanea inhabits relatively higher zones in the upper intertidal zone than A. japonica does, the former species was more likely to be tolerant of the experimental dishes in which the filter paper was wet but not submerged. This may have influenced feeding activities of the snails in the diatom treatment, resulting in the different responses of the stable isotope ratios between the 2 species.

\section{Food sources for macrobenthos in salt marshes}

In estuaries, organic matter in deposited seston (or particulate matter) is derived from several major sources: terrestrial plants, salt marsh plants, phytoplankton and benthic algae. Page (1997) suggested that marsh vascular plant, algal (benthic micro- and macro-algal, phytoplankton), and terrestrial detrital sources are also potentially available to consumers in the salt marshes of southern California. The $\delta^{13} \mathrm{C}$ of terrestrial matter $\left(\mathrm{C}_{3}\right.$ plant: from $-29 \%$ to $-24 \%$ o) is usually isotopically less than that of microalgae (from $-21 \%$ to $-13 \%$ ) (Currin et al. 1995). In the present study, both litter of $C_{3}$ salt marsh plants (Phragmites spp.) and organic matter of surface soil in the salt marshes showed $\delta^{13} \mathrm{C}$ values of about $-26 \%$ (Table 1 ), whereas the $\delta^{13} \mathrm{C}$ of organic matter in deposited seston was approximately $-21 \%$.

An observation on deposited seston collected from the tidal flat, using a binocular microscope, revealed that there were many diatoms, detritus derived from unknown organic matter, copepods and fine inorganic particles. Since the $\delta^{13} \mathrm{C}$ of deposited seston was closer to that of microalgae than to that of reed litter, organic matter from microalgae was considered to be the prin- cipal carbon source in the deposited seston. In addition, the $\mathrm{C} / \mathrm{N}$ of deposited seston was lower than the ratios for litter and soil (Table 1). Vascular plants are more difficult to decompose, with a higher $\mathrm{C} / \mathrm{N}$ ratio, while microalgae, with a lower $\mathrm{C} / \mathrm{N}$, are more easily decomposed; a low $\mathrm{C} / \mathrm{N}$ ratio of detritus indicates a higher quality food for deposit-feeding animals (Tenore 1977, 1981, Grebmeier et al. 1988). Therefore, deposited matter was considered to contain a larger amount of digestible organic matter such as protein derived from microalgae. The snails fed a mixed diet in the feeding experiments may have mainly assimilated the digestible component of deposited matter from the diets provided, and egested a higher number of fecal pellets originating from indigestible reed litter and soil particles.

Over the last few decades, the question of which food source is more important for macro-benthos in salt marsh-vascular plants or microalgae of salt marshes such as phytoplankton and benthic diatoms has been controversial. Peterson et al. (1985) used a combination of the stable isotopes of sulfur, carbon and nitrogen to elucidate the flow of organic matter and trophic relations in salt marshes and estuaries. They showed that the relative importance of marsh grass (Spartina) detritus compared to plankton varied by the location of the mussels in the marsh. Jackson et al. (1986) showed that $S$. anglica was the major carbon source for benthos in salt marshes of eastern England, whereas Sullivan \& Moncreiff (1990) showed that microalgae were important in the salt marsh dominated by $S$. alterniflora in Mississippi. France (1995) studied relationships of the $\delta^{13} \mathrm{C}$ values between aquatic animals and autotrophic food sources including both vascular plants and attached algae, from rivers to estuarine salt marshes, and found that attached algae are likely to play a dietary role in aquatic food webs. Currin et al. (1995) concluded that both benthic microalgae and detrital $S$. alterniflora were important in the salt marshes dominated by S. alterniflora in North Carolina. Page (1997) demonstrated the importance of algal sources, such as benthic algae and phytoplankton, to marsh invertebrate consumers from tidal flats using stable carbon isotopes.

Deegan \& Garritt (1997) found that emergent marsh and benthic algal organic matter sources were more important to benthic organisms, while phytoplankton was more important to pelagic organisms, reporting that differences in isotopic values between pelagic and benthic consumers have been observed in other studies in marine systems. Wainright et al. (2000) found that Phragmites australis may contribute to aquatic food webs in tidal marshes, while phytoplankton may be of lesser importance. They concluded that the relative roles of the primary producers in supplying energy 
to the mummichog Fundulus heteroclitus varies locally and, in particular, with respect to the type of marsh macrophyte vegetation. The mangrove gastropod Terebralia sulcata ingested the organic matter derived from mangrove litter to assimilate the attached bacteria rather than to use the leaves themselves, and benthic and/or planktonic diatoms contributed weakly to the diet of this gastropod (Meziane \& Tsuchiya 2000).

$\mathrm{C}_{4}$ plants (e.g. Spartina spp.) are prevalent in temperate coastal regions of the Western Hemisphere while $\mathrm{C}_{3}$ plants (e.g. Phragmites spp.) are prevalent in tropical and temperate regions of the Eastern Hemisphere (Lee 1990). Both plant types may occupy the equivalent ecological niche in the ecosystems of salt marshes, although this equivalency has been recently questioned (Lee 1990). Most of the studies using stable isotope ratios which examined the relationships between diets and consumers have been conducted in regions where Spartina spp. are prevalent. The $\delta^{13} \mathrm{C}$ values of Spartina spp. are about $-13 \%$ (Currin et al. 1995), and a small difference between the $\delta^{13} \mathrm{C}$ of Spartina spp. and that of microalgae may have been interpreted differently in studies of the relationships between macrobenthos and food sources in salt marshes where Spartina spp. are predominant. In this study, the $\delta^{13} \mathrm{C}$ of reed litter (Phragmites spp.) was about $-25 \%$ (Table 1) and far from the $\delta^{13} \mathrm{C}$ values of benthic diatoms and phytoplankton. Therefore, we were able to unequivocally compare carbon stable isotope ratios between food sources and consumers collected in the field.

Deposited seston collected from the tidal flat in the present study, which was utilized by salt marsh snails as a food source, contained detritus of both vascular plants like Phragmites spp. and microalgae such as benthic diatoms and phytoplankton (authors' pers. obs.). However, the isotopical data suggest that the snails fed on deposited matter with the $\delta^{13} \mathrm{C}$ value more similar to that of microalgae than that of terrestrial plants. It is likely that microalgae constitute the major component of deposited seston because the deposited seston had a lower $\mathrm{C} / \mathrm{N}$ and showed a $\delta^{13} \mathrm{C}$ of about $-21 \%$, which was relatively close to that of microalgae. In conclusion, microalgae such as phytoplankton and benthic diatoms in deposited seston are considered to be important food sources for 2 species of assimineids inhabiting salt marshes of the Nanakita River estuary.

Acknowledgements. We are grateful to T. Kawai for allowing us to use the element analyzer and the mass spectrometer at the National Institute for Environmental Studies. We are also grateful to S. Shikano for reading the manuscript and for his critical comments. We would like to thank S. Aikins for correcting the manuscript, and $\mathrm{T}$. Toya for helping with measurements of stable isotope ratios.

\section{LITERATURE CITED}

Alexander M (1977) Introduction to soil microbiology, 2nd edn. John Wiley \& Sons, New York

Benner R, Fogel ML, Sprague EK (1991) Diagenesis of belowground biomass of Spartina alterniflora in salt-marsh sediments. Limnol Oceanogr 36:1358-1374

Clough LM, Lopez GR (1993) Potential carbon sources for the head-down deposit-feeding polychaete Heteromastus filiformis. J Mar Res 51:595-616

Currin CA, Newell SY, Paerl HW (1995) The role of standing dead Spartina alterniflora and benthic microalgae in salt marsh food webs: considerations based on multiple stable isotope analysis. Mar Ecol Prog Ser 121:99-116

Deegan LA, Garritt RH (1997) Evidence for spatial variability in estuarine food webs. Mar Ecol Prog Ser 147:31-47

France RL (1995) Stable isotopic survey of the role of macrophytes in the carbon flow of aquatic foodwebs. Vegetatio 124:67-72

France RL (1996) Absence or masking of metabolic fractionations of ${ }^{13} \mathrm{C}$ in a freshwater benthic food web. Freshw Biol $36: 1-6$

Fry B, Sherr EB (1984) $\delta^{13} \mathrm{C}$ measurements as indicators of carbon flow in marine and freshwater ecosystems. Contrib Mar Sci 27:13-47

Goering J, Alexander V, Haubenstock N (1990) Seasonal variability of stable carbon and nitrogen isotope ratios of organisms in a North Pacific bay. Estuar Coast Shelf Sci 30:239-260

Gosselink JG, Kirby CJ (1974) Decomposition of salt marsh grass Spartina alterniflora Loisel. Limnol Oceanogr 19: 825-832

Grebmeier JM, McRoy CP, Feder HM (1988) Pelagic-benthic coupling on the shelf of the northern Bering and Chukchi Seas. I. Food supply source and benthic biomass. Mar Ecol Prog Ser 48:57-67

Gu B, Alexander V, Schell DM (1997) Stable isotopes as indicators of carbon flows and trophic structure of the benthic food web in a subarctic lake. Arch Hydrobiol 138:329-344

Haines EB, Montague CL (1979) Food sources of estuarine invertebrates analyzed using ${ }^{13} \mathrm{C} /{ }^{12} \mathrm{C}$ ratios. Ecology 60 : $48-56$

Hammond LS (1983) Nutrition of deposit-feeding holothuroids and echinoids (Echinodermata) from a shallow reef lagoon, Discovery Bay, Jamaica. Mar Ecol Prog Ser 10:297-305

Hedges JI, Clark WA, Cowie GL (1988) Organic matter sources to the water column and surficial sediments of a marine bay. Limnol Oceanogr 33:1116-1136

Heip CHR, Goosen NK, Herman PMJ, Kromkamp J, Middelburg JJ, Soetaert K (1995) Production and consumption of biological particles in temperate tidal estuaries. Oceanogr Mar Biol Annu Rev 33:1-149

Hobson KA, Welch HE (1992) Determination of trophic relationships within a high Arctic marine food web using $\delta^{13} \mathrm{C}$ and $\delta^{15} \mathrm{~N}$ analysis. Mar Ecol Prog Ser 84:9-18

Hobson KA, Alisauskas RT, Clark RG (1993) Stable-nitrogen isotope enrichment in avian tissues due to fasting and nutritional stress: implications for isotopic analysis of diet. Condor 95:388-394

Hodson RE, Christian RR, Maccubbin AE (1984) Lignocellulose and lignin in the salt marsh grass, Spartina alterniflora: initial concentrations and short-term post-depositional changes in detrital material. Mar Biol 81:1-7

Hullar MAJ, Fry B, Peterson BJ, Wright RT (1996) Microbial utilization of estuarine dissolved organic carbon: a stable isotope tracer approach tested by mass balance. Appl Environ Microbiol 62:2489-2493 
Jackson D, Harkness DD, Mason CF, Long SP (1986) Spartina anglica as a carbon source for salt-marsh invertebrates: a study using $\delta^{13} \mathrm{C}$ values. Oikos 46:163-170

Kikuchi E, Wada E (1996) Carbon and nitrogen stable isotope ratios of deposit-feeding polychaetes in the Nanakita River estuary, Japan. Hydrobiologia 321:69-75

Kristensen JH (1972) Carbohydrases of some marine invertebrates with notes on their food and on the natural occurrence of the carbohydrates studied. Mar Biol 14:130-142

Kurata K, Kikuchi E (1999) Life cycle and production of Assiminea japonica v. Martens and Angustassiminea castanea (Westerlund) (Gastropoda: Assimineidae) at a reed marsh in Gamo lagoon, northern Japan. Ophelia 50:191-214

Kurata K, Kikuchi E (2000) Comparisons of life-history traits and sexual dimorphism between Assiminea japonica and Angustassiminea castanea (Gastropoda: Assimineidae). J Molluscan Stud 66:177-196

Kwak TJ, Zedler JB (1997) Food web analysis of southern California coastal wetlands using multiple stable isotopes. Oecologia 110:262-277

Lee SY (1990) Net aerial primary productivity, litter production and decomposition of the reed Phragmites communis in a nature reserve in Hong Kong: management implications. Mar Ecol Prog Ser 1990:161-173

Lopez GR, Levinton JS, Slobodkin LB (1977) The effect of grazing by the detritivore Orchestia grillus on Spartina litter and its associated microbial community. Oecologia 30:111-127

Matsubara T, Minami H (1998) Stable isotope analysis in avian ecology: present and future perspective. J Yamashina Inst Ornithol 30:59-82 (in Japanese)

Meziane T, Tsuchiya M (2000) Fatty acids as tracers of organic matter in the sediment and food web of a mangrove/intertidal flat ecosystem, Okinawa, Japan. Mar Ecol Prog Ser 200:49-57

Minagawa M, Wada E (1984) Stepwise enrichment of ${ }^{15} \mathrm{~N}$ along food chains: further evidence and the relation between $\delta^{15} \mathrm{~N}$ and animal age. Geochim Cosmochim Acta 48:1135-1140

Minami H, Ogi H (1997) Determination of migratory dynamics of the sooty shearwater in the Pacific using stable carbon and nitrogen isotope analysis. Mar Ecol Prog Ser 158:249-256

Moran MA, Hodson RE (1990) Contributions of degrading Spartina alterniflora lignocellulose to the dissolved organic carbon pool of a salt marsh. Mar Ecol Prog Ser 62:161-168

Editorial responsibility: Kenneth Tenore,

Solomons, Maryland, USA
Newell R (1965) The role of detritus in the nutrition of two marine deposit feeders, the prosobranch Hydrobia ulvae and the bivalve Macoma balthica. Proc Zool Soc Lond 144: $25-45$

Page HM (1997) Importance of vascular plant and algal production to macro-invertebrate consumers in a southern California salt marsh. Estuar Coast Shelf Sci 45:823-834

Peterson BJ, Howarth RW, Garritt RH (1985) Multiple stable isotopes used to trace the flow of organic matter in estuarine food webs. Science 227:1361-1363

Rau GH, Mearns AJ, Young DR, Olson RJ, Schafer HA, Kaplan IR (1983) Animal ${ }^{13} \mathrm{C} /{ }^{12} \mathrm{C}$ correlates with trophic level in pelagic food webs. Ecology 64:1314-1318

Sullivan MJ, Moncreiff CA (1990) Edaphic algae are an important component of salt marsh food-webs: evidence from multiple stable isotope analyses. Mar Ecol Prog Ser 62:149-159

Tenore KR (1975) Detrital utilization by the polychaete, Capitella capitata. J Mar Res 33:261-274

Tenore KR (1977) Growth of Capitella capitata cultured on various levels of detritus derived from different sources. Limnol Oceanogr 22:936-941

Tenore KR (1981) Organic nitrogen and caloric content of detritus. I. Utilization by the deposit-feeding polychaete, Capitella capitata. Estuar Coast Shelf Sci 12:39-47

Thompson LS (1984) Comparison of the diets of the tidal marsh snail, Melampus bidentatus and the amphipod, Orchestia grillus. Nautilus 98:44-53

Uthicke S (1999) Sediment bioturbation and impact of feeding activity of Holothuria (Halodeima) atra and Stichopus chloronotus, two sediment feeding holothurians, at Lizard Island, Great Barrier Reef. Bull Mar Sci 64:129-141

Wada E, Terazaki M, Kabaya Y, Nemoto T (1987) ${ }^{15} \mathrm{~N}$ and ${ }^{13} \mathrm{C}$ abundances in the Antarctic Ocean with emphasis on the biogeochemical structure of the food web. Deep-Sea Res 34:829-841

Wainright SC, Weinstein MP, Able KW, Currin CA (2000) Relative importance of benthic microalgae, phytoplankton and the detritus of smooth cordgrass Spartina alterniflora and the common reed Phragmites australis to brackishmarsh food webs. Mar Ecol Prog Ser 200:77-91

Yamada Y, Yoshioka T (1999) Stable isotope analysis in aquatic ecosystems. Jpn J Ecol 49:39-45 (in Japanese)

Yingst JY (1976) The utilization of organic matter in shallow marine sediments by an epibenthic deposit-feeding holothurian. J Exp Mar Biol Ecol 23:55-69

Submitted: October 15, 1999; Accepted: November 27, 2000

Proofs received from author(s): November 15, 2001 